\title{
Effects of grazing on species composition of the epilithic algal community on coral reefs of the central Great Barrier Reef
}

\author{
Fiona J. Scott, Garry R. Russ* \\ Department of Botany, James Cook University of North Queensland, Townsville, Queensland, Australia \\ and \\ Australian Institute of Marine Science, PMB No. 3, Townsville M. C., Queensland, Australia
}

\begin{abstract}
Coral blocks were used as settlement surfaces to study the epilithic algal community (EAC) in the presence and short-term absence of large, herbivorous grazers on the central Great Barrier Reef (GBR). Grazers were excluded by cages at study sites on 2 inshore, 2 midshelf and 2 outershelf reef. Of 82 algal taxa recorded, 81 were small filamentous or fleshy 'algal turfs' Composition and abundance of algae differed greatly between caged and uncaged substrata, with differences more pronounced on mid-and outershelf reefs than on inshore reefs. Caged surfaces on inshore reefs were dominated by Sphacelaria novae-hollandiae (Phaecophyta), an assemblage of Oscillatoriaceae (Cyanophyta), Acetabularia calyculus (Chlorophyta), Ceramium flaccidum, Taenioma nanum and Polysiphonia infestans (all Rhodophyta) and Cladophora fasicularis (Chlorophyta). Caged surfaces on mid-and outershelf reefs were dominated by Enteromorpha clathrata (Chlorophyta), P. infestans, Polysiphonia sphaerocarpa, C. flaccidum, Merposiphonia secunda f. tenella and Lobophora variegata (all Rhodophyta), S. novaehollandiae, assemblages of Oscillatoriaceae and Nostocaceae (Cyanophyta), Giffordia mitchellae and ? Pseudopringsheimia (both Chlorophyta). These species are likely to account for a large proportion of algal production and food of large, herbivorous grazers on these reefs. Uncaged surfaces on inshore reefs were dominated by $S$. novae-hollandiae, an assemblage of Oscillatoriaceae, G. mitchellae and $P$. sphaerocarpa; those on mid- and outershelf reefs by the crustose coralline alga Porolithon onkodes, assemblages of Nostocaceae and Oscillatoriaceae, ? Pseudopringsheimia, Polysiphonia scopulorum and Ceramium punctiforme. Location on the continental shelf accounted for the major proportion of variability in the data due mainly to the distribution of $P$. onkodes. When this species was omitted from the analysis, the effect of excluding grazers in combination with differences between inshore and mid-/outershelf reefs accounted for the major proportion of variability. In the latter analysis, location was a far less important component of variability in EAC omposition than was presence or absence of grazers, because of large between-reef (i.e. within-location) variance in the abundance of many species. Grazers have a greater impact on composition and abundance of the EAC on mid- and outershelf reefs than on inshore reefs, in agreement with previous findings that herbivorous, grazing fishes are significantly less abundant on inshore than on mid- and outershelf reefs.
\end{abstract}

\section{INTRODUCTION}

The epilithic algal community (EAC) on most coral reefs is characterized by a small standing crop, a fast rate of primary productivity and a high species richness. It is usually dominated by aggregates of small filamentous and fleshy algae with developmental stages of larger algae ('algal turfs') together with crus- Addressee for reprint requests: present address: Depart-
ment of Zoology, University of Sydney, N.S.W. 2006, Australia tose coralline algae. The EAC is the major source of primary production on coral reefs (e.g. Wanders 1977 , Hatcher 1983, Carpenter 1985a, Gladfelter \& Kinsey 1985) and the yield of the EAC to grazing orgamisms is possibly the largest trophic flux on coral reefs (Carpenter 1981, 1986, Hatcher 1981, Hatcher \& Larkum 1983). Despite these characteristics there is very little information available on the algal species likely to account for the very fast rates or organic production on coral reefs and which are likely to constitute the food of herbivorous grazers. There is also a marked paucity of information on the effects of grazers on the species 
richness and composition of the EAC and on the abundance of individual algal species, particularly on the Great Barrier Reef (GBR), especially over spatial scales of tens of kilometres. This situation has arisen mainly from the great taxonomic difficulties associated with the EAC and the lack of studies at large spatial scales. The taxonomic problems, particularly for the algal turfs, are currently being addressed (e.g. Cribb 1983, Price \& Scott unpubl.).

A co-ordinated effort to characterize the broad-scale patterns of distribution and abundance of coral reef biota in the central GBR has existed for some time (reef fishes: Williams 1982, 1983, Williams \& Hatcher 1983, Russ 1984a, b; hard corals: Done 1982; soft corals: Dinesen 1983; calcified green algae: Drew 1983). These studies have concentrated upon determining patterns of distribution and abundance of organisms among reefs along a transect across the GBR continental shelf from the Australian mainland to the Coral Sea. The present study is a component of a project investigating the rate of production of algal tissue and rate of trophic exchange between the EAC and large grazers (Williams et al. 1986, Russ unpubl. data).

The aims of this study were to determine the species composition of the epilithic algal community on coral reefs of the central GBR, and the impact of short-term ( $1 \mathrm{mo}$ ) exclusion of grazers on the composition of the EAC. The species of algae likely to account for most of the algal production and the food of larger herbivorous grazers on these coral reefs were identified, and differences in the abundance of individual algal species across the continental shelf were determined.

\section{MATERIALS AND METHODS}

Study sites. The study was conducted at 6 reefs on the continental shelf in the central region of the Great Barrier Reef (Fig. 1). All 6 reefs had been included in previous surveys of the distribution and abundance of large, herbivorous grazing fishes (Russ 1984a, bj. Two reefs were located inshore, approximately $10 \mathrm{~km}$ from the coast (Pandora, Lorne), 2 on the midshelf, approximately $50 \mathrm{~km}$ from the coast (Rib, John Brewer), and 2 on the outershelf, approximately $100 \mathrm{~km}$ from the coast (Myrmidon, Dip). The gross morphology and environment of the study reefs has been described by Done (1982).

A single topographic zone (the crests of leeward patch reefs) was studied at each reef. Inshore reefs were small and lacked the distinctive pattern of zonation of mid-and outershelf reefs, e.g. no true reef crest, flat, lagoon or reef slope (Done 1982). The leeward crest was selected because it was the only zone which was directly comparable on all 6 reefs. Two study sites were located on the leeward crests of each of the 6 reefs. This zone is relatively sheltered from strong wave action, although this is not always the case for the outershelf reefs. The depth of all study sites within this zone varied from 0.5 to $2.0 \mathrm{~m}$. On very rare occasions, study sites on the mid-and outershelf reefs may have been exposed to air during very low spring tides.

Experimental design. Coral blocks $8 \mathrm{~cm} \times 8 \mathrm{~cm}$ and $2.5 \mathrm{~cm}$ thick were cut from Porites spp. and used as surfaces for settlement of algae. Flat, square surfaces were chosen because they permitted rapid and effec-

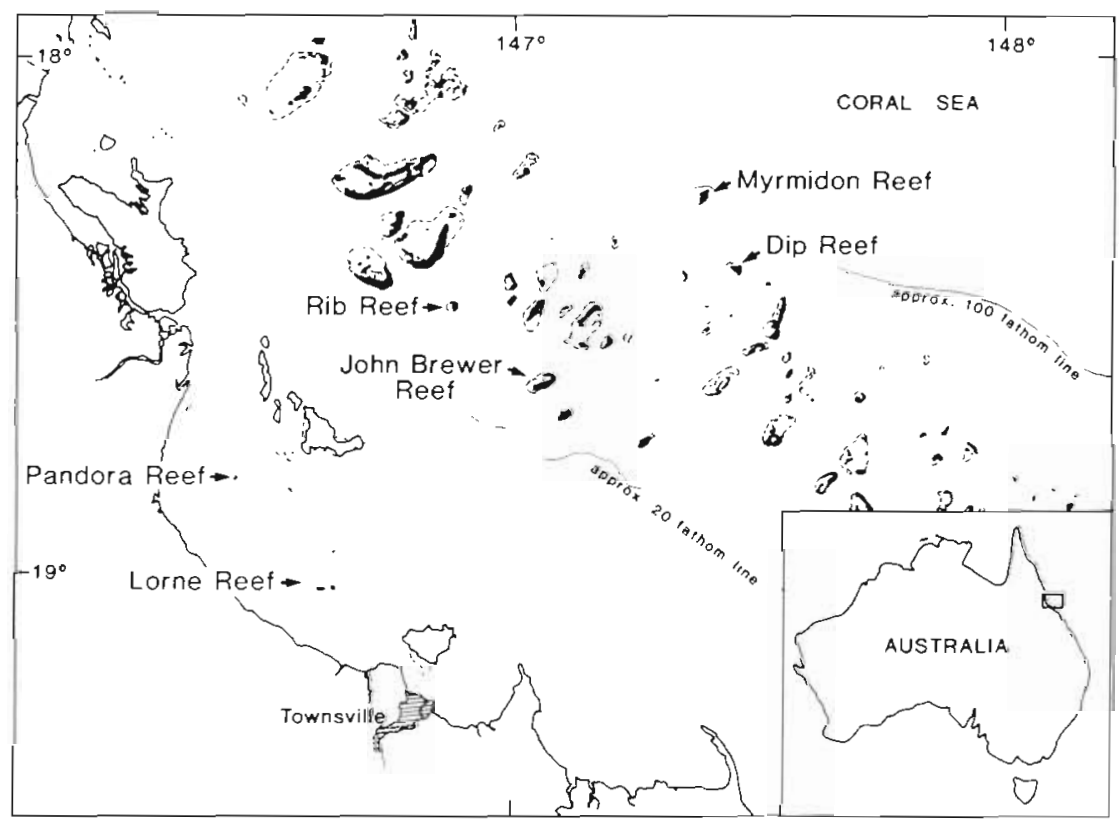

Fig. 1. Location of study reefs in the central Great Barrier Reef region 
tive removal of algal biomass by scraping, and rapid determination of the upper surface area. Each coral block had a $7 \mathrm{~mm}$ diameter hole drilled through its centre and was attached directly to the natural substratum using a stainless steel coach screw. Three pairs of coral blocks were attached at each site and each block in a pair was placed within 1 to $2 \mathrm{~m}$ of the other, whilst the 3 pairs were placed haphazardly over an area of approximately 75 to $150 \mathrm{~m}^{2}$. The blocks at Pandora, Rib, John Brewer and Myrmidon were immersed in mid-September, whilst blocks at Dip and Lorne reefs were immersed in mid-August and early October respectively (austral spring). After the initial period of immersion (4 mo at Lorne, $4.5 \mathrm{mo}$ at Pandora, Rib, John Brewer and Myrmidon, 5.5 mo at Dip) - a period allowing development of an EAC which appeared visually to approximate that of the surrounding natural substratum - one of each pair of blocks at each site was enclosed in a $12.5 \times 12.5 \times 6.25 \mathrm{~cm}$ galvanized mesh cage (mesh size $=12.5 \mathrm{~mm}$ square, wire diameter $=0.8 \mathrm{~mm}$ ), for a period of approximately $30 \mathrm{~d}$, beginning in late January 1985. The cages excluded all grazers larger than $12.5 \mathrm{~mm}$ minimum dimension. An identical method has been used to measure grazing rates of algae inside and outside territories of a tropical damselfish (Russ in press). Exact durations of the caging treatments were $32 \mathrm{~d}$ (Pandora, Lorne), 30 d (Rib), 29 d (John Brewer), 26 d (Myrmidon), and 24 d (Dip). There were 2 treatments (caged and uncaged) replicated 3 times at each site and there were 2 sites within the single zone studied (the leeward reef crest) on 2 reefs per location and 3 locations (inshore, midshelf, outershelf). Coral blocks were removed in late February 1985 (late summer) and upon removal were placed into individual self-seal polyethylene bags in situ and frozen immediately upon return to the ship.

Estimates of abundance of species. After thawing, each block was placed in a dish and covered with seawater. Only the upper surface of the block was examined, and this was divided into 36 quadrats of $12.5 \times 12.5 \mathrm{~mm}$ for analysis. Except for the 4 central quadrats (which were influenced by the presence of a $15 \mathrm{~mm}$ diameter PVC washer) an initial visual estimate of percentage cover to the nearest $25 \%$ was made for each quadrat. Percentages of each of the following 6 categories were recorded: bare substratum, crustose coralline algae and turf algae in categories of $<1,1$ to 3 , 3 to 6 , and $>6 \mathrm{~mm}$ high. Five quadrats were then chosen at random (excluding the 4 central ones) and examined with a dissecting microscope. All algae within these quadrats were identified to species or generic level which often required the use of a compound microscope. The percentage cover of individual canopies was estimated by allotting them to one of the following categories: $1=1$ to $10 \%$ cover; $2=11$ to $25 \% ; 3=26$ to
$50 \% ; 4=>50 \%$. Species not recorded within the 5 random quadrats and not observed previously during the study were recorded as 'Incidental Species' and included in the final species list. Reference specimens (microscope preparations) were lodged in the herbarium at James Cook University (Nos. JCT A7106, $7112-4,7122-3,7170,7203-4,7217-7375)$.

Effects of cages. The method proposed by Kennelly (1983) was used to test for any effects of the cages other than that of excluding large grazers. The experiment was carried out at a depth of approximately $1.5 \mathrm{~m}$ at Rib Reef in October 1985 and consisted of 4 treatments: caged and uncaged blocks as described above, and caged and uncaged blocks placed within a large galvanized mesh cage ( $2.5 \mathrm{~m}$ square, $1 \mathrm{~m}$ high), with a circular mesh size of $1.9 \mathrm{~cm}$ diameter. Placing both caged and uncaged blocks inside a much larger cage partitions the effect of exclusion of large grazers from any other effects the small cage may have (such as modification of light intensity or water movement). There were 6 replicates of each treatment. The EAC on these blocks was analysed as described above.

Analysis of data. Four-factor analyses of variance were carried out on the species richness data and on percentage cover estimates for 2 major categories (crustose corallines, and algal turfs $>1 \mathrm{~mm}$ high). Multiple comparisons of means (at a significance level of 0.05) were carried out using the Student-NewmanKeuls (SNK) procedure (Winer 1971). The 82 taxa obtained from the 72 coral blocks used $(6$ blocks $\times 2$ sites $\times 6$ reefs) were defined arbitrarily as rare if recorded on $<5$ blocks, common if on 6 to 25 blocks, abundant if on 25 to 36 blocks and dominant if on $>36$ blocks. Thirty of the 85 taxa were considered common enough for detailed analysis. For each of these 30 taxa, the abundance estimates from random quadrats on a block were pooled, and the data (30 taxa $\times 72$ blocks) subjected to an agglomerative, hierarchical classification (Williams 1971). Bray-Curtis similarity coefficients (Bray \& Curtis 1957) were calculated between all 72 blocks, the 2 most similar blocks fused to form a cluster, and the process was repeated using Burr's incremental sum of squares strategy (Burr 1970). The analysis was run using CSIRO's SAHN program (Williams \& Lance 1977). This analysis indicated that the crustose coralline alga Porolithon onkodes (the only species which was not a filamentous or fleshy 'turf' alga) accounted for a large proportion of the variability in the data set (see Fig. 3). An identical analysis was therefore run excluding $P$. onkodes. The Cramer value was used as a diagnostic to estimate the relative contribution of each species to the discrimination of particular groups produced by the classification analysis (Lance \& Williams 1977). A classification analysis identical to those described above was carried out for the caged 
and uncaged blocks within the large cage to test for the effects of the small cage on composition of the EAC.

Species richness and percentage cover estimates for crustose corallines, algal turfs $>1 \mathrm{~mm}$ high, and individual species are presented graphically. Cover data for crustose corallines and algal turfs $>1 \mathrm{~mm}$ high are derived from estimates made from all 32 quadrats on a block. Cover data for individual species are estimated using the abundance category data from 5 random quadrats on a block. The approximate mid-point of an abundance category was taken as the 'best estimate' of actual cover i.e. Category $1=5 \%$, Category $2=15 \%$, Category $3=35 \%$, Category $4=60 \%$. Dense mats of algal turf, in which the canopies of many species overlapped and in which Category 4 estimates were common, sometimes led to an estimate of total cover $>100 \%$.

\section{RESULTS}

\section{Cage control experiment}

The small experimental cages had no significant effect upon the species composition of the EAC apart from the effect of grazer exclusion (Fig. 2 and test of Sandland \& Young 1979a, b). There was no significant difference in $\%$ cover of algal turfs $>1 \mathrm{~mm}$ high between the 2 small-cage treatments $-i$.e. inside $(\overline{\mathrm{x}}=$ $59.73 \%, 95 \% \mathrm{CL}=27.18)$ and outside $(\overline{\mathrm{x}}=45.88 \%$, $95 \% \mathrm{CL}=17.07)$ the large cage - and the treatment

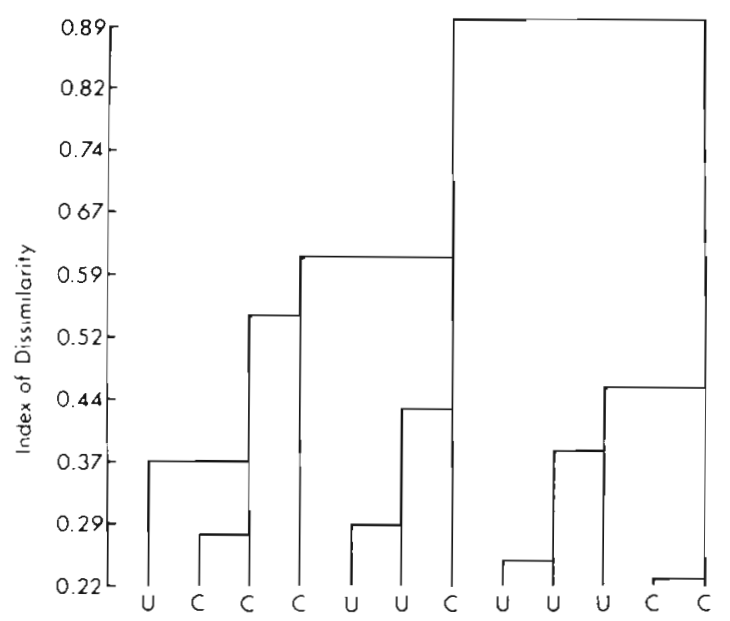

Fig. 2. Dendrogram from the classification analysis of the 30 most common taxa of algae (from Table 1) on 6 caged (C) and 6 uncaged (U) blocks inside the large cage described in the cage control experiment. Major splits in the dendrogram represent distinct differences in the species composition of the epilithic algal communjty (EAC). The fact that caged and uncaged substrata show no obvious pattern of clustering indicates that the presence of a small cage had no significant effect upon the species composition of the EAC without a small cage but enclosed in the large cage $(\bar{x}=50.73 \%, 95 \% \mathrm{CL}=22.75)$. Again, this indicates that the small cage had no significant effect upon the $\%$ cover of algal turfs on blocks, apart from the effect of grazer exclusion.

Cross-shelf experiment. Table 1 lists the 82 taxa of algae recorded in this study. A total of 52 taxa ( $63 \%$ ) were classified as rare.

There was a significant interaction between the effects of excluding grazers and the location of the reefs on the continental shelf (analysis of variance; Table 2). Species richness was significantly greater on caged than uncaged blocks at Rib, John Brewer and Myrmidon reefs, but did not differ significantly at Dip and the 2 inshore reefs (Fig. 3 and SNK tests). For caged blocks there were no significant differences in species richness between any of the 6 reefs, but species richness on uncaged blocks at Myrmidon and Rib reefs was significantly less than at the other 4 reefs (Fig. 3 and SNK tests).

There was a significantly greater cover of crustose corallines on uncaged than caged blocks and signifi-

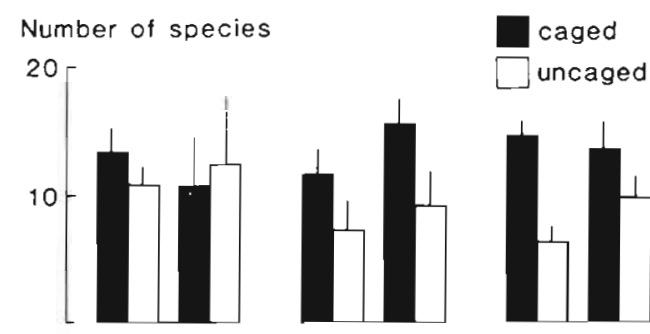

\% Cover crustose corallines

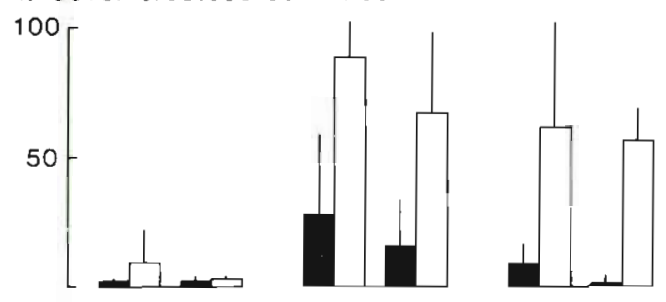

\% Cover algal turf $>1 \mathrm{~mm}$ ht.

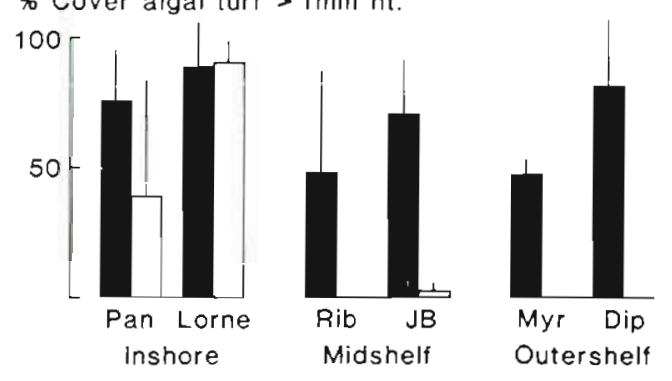

Fig. 3. Mean number of species of algae, mean \% cover of the crustose coralline alga Porolithon onkodes, and mean \% cover of algal turfs $>1 \mathrm{~mm}$ in height on caged and uncaged blocks on reefs across the continental shelf. Sites are pooled for each reef. Reefs are: Pan (= Pandora), Lorne, Rib, JB (= John Brewer), Myr (= Myrmidon), Dip 
Table 1. List of the 82 benthic algal taxa recorded on the 72 coral substrata in this study. Frequency of occurrence: $R$, rare (recorded on $\leqslant 5$ blocks); C, common (6 to 25 blocks); A, abundant ( 25 to 36 blocks); D, dominant ( $>36$ blocks). Presence of the

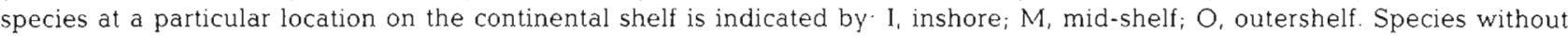
information on their location refer to 'Incidental Species'

\begin{tabular}{|c|c|c|c|}
\hline Algal taxon & currence & Algal taxon & Occurrence \\
\hline \multicolumn{2}{|l|}{ RHODOPHYTA } & Polysiphonia sphaerocarpa Borgesen & C, IMO \\
\hline Amansia glomerata C. Agardh & R, I & Polysiphonia sp. 1 & A, IMO \\
\hline Amphiroa foliacea Lamouroux & $\mathrm{R}, \mathrm{IO}$ & Polysiphonia sp. 2 & $\mathrm{R}$ \\
\hline Anotrichium tenue (C. Agardh) Naegeli & $\mathrm{R}, \mathrm{I}$ & Porolithon onkodes (Heydrich) Foslie & $\mathrm{D}, \mathrm{IMO}$ \\
\hline Antithamnionella sp. & $\mathrm{R}, \mathrm{IM}$ & Spyridia filamentosa (Wulfen) Harvey & $\mathrm{R}, \mathrm{I}$ \\
\hline Crouanieae sp. indet. & $\mathrm{R}, \mathrm{M}$ & & C, IM \\
\hline Caulacanthus indicus Weber-van Bosse & $\mathrm{R}$ & & \\
\hline Centroceras apiculatum Yamada & $\mathrm{R}, \mathrm{O}$ & $\begin{array}{l}\text { Toylpiocladia glomerulata (C. Agardh) Schmitz } \\
\text { in Schmitz \& Hauptfleisch }\end{array}$ & $\mathrm{R}_{1} \mathrm{I}$ \\
\hline Centroceras clavulatum (C. Agardh) Montagne & C. IMO & Wrangelia argus (Montagne) Montagne & $\mathrm{R}, \mathrm{M}$ \\
\hline Ceramiella huysmansii Weber-van Bosse & $\mathrm{R}$ & \\
\hline Ceramium ?codii (Richards) Mazoyer & C. IO & \multicolumn{2}{|l|}{ CHLOROPHYTA } \\
\hline Ceramium flaccidum (Kuetzing) Aridissone & D, IMO & \multirow{2}{*}{ Acetabularia calyculus Quoy \& Gaimard } & C, IM \\
\hline Ceramium isogonum Harvey & $\mathrm{R}, \mathrm{IM}$ & & C, I \\
\hline Ceramium macilentum J. Agardh & $\mathrm{R}, \mathrm{IM}$ & Boodlea composita (Harvey) Brand & $\mathrm{R}, \mathrm{I}$ \\
\hline Ceramium ?marshallense Dawson & $\mathrm{R}$ & Bornetella sphaerica (Zanardini) Solms-Lubach & $\mathrm{R}$ \\
\hline Ceramium maryae Weber-van Bosse & $\mathrm{C}, \mathrm{MO}$ & Bryopsis indica Gepp \& Gepp & $\mathrm{R}$ \\
\hline Ceramium punctiforme Setchell & A, $\mathrm{MO}$ & Chlorodesmis major Zanardini & $\mathrm{R}$ \\
\hline Ceramium sp. 1 & $\mathrm{R}, \mathrm{O}$ & \multicolumn{2}{|l|}{ Cladophora fasicularis (Mertens ex C. Agardh) } \\
\hline Ceramium sp. 2 & $\mathrm{R}, \mathrm{MO}$ & \multirow{2}{*}{\multicolumn{2}{|c|}{$\begin{array}{l}\text { Kuetzing } \\
\text { Cladophoropsis ?membranacea (C. Agardh) }\end{array}$}} \\
\hline Champia vieillardii Kuetzing & R, IM & & \\
\hline Chondria sp. 1 & $\mathrm{R}, \mathrm{I}$ & \multirow{2}{*}{\multicolumn{2}{|c|}{$\begin{array}{ll}\text { Børgesen } & \text { R, I } \\
\text { 2Dasycladus } & \text { C IO }\end{array}$}} \\
\hline Chondria sp. 2 & $\mathrm{R}, \mathrm{I}$ & & \\
\hline Chondria sp. 3 & C. IMO & Derbesia sp. & R, IM \\
\hline Chondria sp. 4 & $\mathrm{R}$ & Enteromorpha clathrata (Roth) J. Agardh & D. IMO \\
\hline Crouania attenuata (C. Agardh) J. Agardh & $\mathrm{R}$ & Enteromorpha sp. & $\mathrm{R}$ \\
\hline Erythrotrichia sp. & R, I & Entocladia sp. & R, I \\
\hline Gelidiella pannosa (Feldmann) Feldmann \& & $\pi, 1$ & ?Pseudopringsheimia & D. $I M O$ \\
\hline Hamel & C, IMO & Rhizoclonium sp. & $\mathrm{R}, \mathrm{IM}$ \\
\hline Gelidiopsis sp. & $\mathrm{R}, \mathrm{I}$ & Struvea anastomosans (Harvey) & \\
\hline Gelidium sp. & $\mathrm{R}, \mathrm{I}$ & Grunow ex Piccone & $\mathrm{R}$ \\
\hline ?Goniotrichopsis & $\mathrm{R}$ & Udotea javensis (Montagne) Gepp \& Gepp & $\mathrm{R}$ \\
\hline Griffithsia subcylindrica Okamura & $\mathrm{R}, \mathrm{IM}$ & PHAEOPHYTA & \\
\hline Herposiphonia secunda forma & & Dictyota ?bartayresii Lamouroux & $\mathrm{R}$ \\
\hline (C. Agardh) Ambronn & C. IMO & Giffordia mitchellae (Harvey) Hamel & A, IMO \\
\hline Herposiphonia secunda forma & & Lobophora variegata (Lamouroux) Womersley & C. IMO \\
\hline (C. Agardh) Wynne & A, IMO & Padina sp. (Vaughniella stage) & C. IMO \\
\hline Heterosiphonia wurdemanni var. laxa Børgesen & $\mathrm{R}$ & Sphacelaria novae-hollandiae Sonder & D. IMO \\
\hline Hypnea pannosa J. Agardh & $\mathrm{R}$ & & \\
\hline Hypnea spinella (C. Agardh) Kuetzing & $\mathrm{R}, \mathrm{I}$ & CYANOPHYTA & \\
\hline Hypoglossum sp. & $\mathrm{R}$ & Calothrix sp. 1 & $\mathrm{R}$ \\
\hline Jania adhaerens Lamouroux & C. IMO & Lyngbya majuscula (Dillwyn) Harvey ex Gomont & C. IM \\
\hline Laurencia ?humilis Setchell \& Gardner & $\mathrm{C}, \mathrm{MO}$ & Nostocaceae assemblage & D, IMO \\
\hline Laurencia ?majuscula (Harvey) Lucas & $\mathrm{R}, \mathrm{M}$ & including Scytonema sp. & \\
\hline Laurencia obtusa (Hudson) Lamouroux & $\mathrm{R}, \mathrm{M}$ & Calothrix sp. 1 & \\
\hline Laurencia succisa Cribb & $\mathrm{R}$ & Calothrix sp. 2 & \\
\hline Laurencia sp. & $\mathrm{R}, \mathrm{I}$ & Oscillatoriaceae assemblage & $\mathrm{D}, \mathrm{IMO}$ \\
\hline Lomentaria corallicola Borgesen & $\mathrm{R}, \mathrm{MO}$ & including Lynybya majuscula (Dillwyn) & \\
\hline Monosporus indicus Borgesen & $\mathrm{R}, \mathrm{I}$ & Harvey ex Gomont & \\
\hline Polysiphonia exilis Harvey & $\mathrm{R}, \mathrm{I}$ & Lynybya sp. 1 & \\
\hline Polysiphonia infestans Harvey & C. IMO & Lynybya sp. 2 & \\
\hline Polysiphonia poko Hollenberg & $\mathrm{R}, \mathrm{IM}$ & Lynybya sp. 3 & \\
\hline Polysiphonia scopulorum Harvey & $\mathrm{C}, \mathrm{O}$ & Plectonema sp. & \\
\hline
\end{tabular}

cantly greater cover at the mid- and outershelf locations than inshore (analysis of variance in Table 2 and SNK tests; see Fig. 3). The height of algal turfs on most caged blocks plus uncaged blocks from inshore reefs was generally 1 to $6 \mathrm{~mm}$. Turf algae rarely exceeded 1 $\mathrm{mm}$ in height on uncaged blocks of the mid- and outershelf reefs (Fig. 3). There was a significantly greater \% cover of turf algae on caged than uncaged blocks 
Table 2. Summary of results of 4 -factor analyses of variance on species richness of turf algae and on percentage cover estimates of crustose corallines and algal turfs greater than $1 \mathrm{~mm}$ in height. The 4 factors in the analyses were location on the continental shelf (inshore, midshelf, outershelf), reefs nested within locations, sites nested within reefs, and caging treatments (caged, uncaged) within sites. Location and caging treatments were fixed factors; reefs and sites random factors (Underwood 1981). There were 3 replicates within each combination of the 4 factors. Homogeneity of variance for all analyses was determined using Cochran's Test (Winer 1971). To overcome significant heterogeneity of variances the raw data were transformed as follows: number of species $(1 / \mathrm{x}), \%$ cover corallines (log $[\operatorname{arcsine} \mathrm{x}+1])$, \% cover algal turfs $>1 \mathrm{~mm}$ height (arcsine $\mathrm{x}$ ). MS: mean square; F: F-ratio; p: probability level; ns: non-significant

\begin{tabular}{|c|c|c|c|c|c|c|c|c|c|c|}
\hline \multirow[t]{2}{*}{$\begin{array}{l}\text { Source of } \\
\text { variation }\end{array}$} & \multirow[t]{2}{*}{$\begin{array}{l}\text { Degrees of } \\
\text { freedom }\end{array}$} & \multicolumn{3}{|c|}{$\begin{array}{l}\text { Species richness of } \\
\text { turf algae }\end{array}$} & \multicolumn{3}{|c|}{$\begin{array}{c}\% \text { Cover } \\
\text { crustose corallines }\end{array}$} & \multicolumn{3}{|c|}{$\begin{array}{c}\% \text { Cover } \\
\text { algal turfs }>1 \mathrm{~mm} \text { ht. }\end{array}$} \\
\hline & & MS & $F$ & $\mathrm{p}$ & MS & F & $\mathrm{p}$ & MS & $\mathrm{F}$ & $\mathrm{p}$ \\
\hline Location on shelf & 2 & 0.0026 & 0.84 & ns & 5.82 & 50.61 & $<0.01$ & 9716.8 & 5.84 & ns \\
\hline Reefs (Locations) & 3 & 0.0031 & 15.50 & $<0.01$ & 0.12 & 0.35 & ns & 1665.4 & 5.16 & $<0.05$ \\
\hline Sites (Reefs [Locs.]) & 6 & 0.0002 & 0.36 & ns & 0.33 & 1.58 & ns & 322.8 & 1.43 & ns \\
\hline Cages & 1 & 0.0330 & 12.55 & $<0.05$ & 7.85 & 20.12 & $<0.05$ & 28455.8 & 35.49 & $<0.01$ \\
\hline Locations $\times$ Cages & 2 & 0.0048 & 1.83 & ns & 0.06 & 0.16 & ns & 3066.1 & 3.82 & ns \\
\hline Reefs $\times$ Cages & 3 & 0.0026 & 13.15 & $<0.01$ & 0.39 & 0.96 & ns & 801.6 & 1.76 & ns \\
\hline Sites $\times$ Cages & 6 & 0.0002 & 0.36 & ns & 0.41 & 1.94 & ns & 455.1 & 2.02 & ns \\
\hline Residual & 48 & 0.0006 & & & 0.21 & & & 225.3 & & \\
\hline
\end{tabular}

and significantly greater \% cover at Lorne Reef than Pandora Reef; both of these reefs had significantly greater cover than the other 4 (analysis of variance in Table 2 and SNK tests; see Fig. 3).

Blocks from inshore reefs were separated clearly from all the blocks from mid-and outershelf reefs in the classification analysis (Fig. 4a). Amongst the inshore reefs, Pandora and Lorne had distinct epilithic algal communities (EAC) (Fig. 4a). Amongst the reefs further from the coast, the mid-and outershelf reefs also had EACs distinct from each other, with a greater difference between caged and uncaged blocks on midshelf reefs than outershelf reefs (Fig. 4a). When Porolithon onkodes was omitted from the analysis, all uncaged blocks were distinct from the caged blocks plus uncaged blocks from inshore reefs (Fig. 4b). Those taxa contributing most to the discrimination between the EAC of inshore reefs with that on mid- and outershelf reefs in Fig. $4 \mathrm{~b}$ are listed in Table 3 and an estimate of the percentage cover of each of these taxa on caged and uncaged substrata at each of the 6 reefs is provided in Table 4 . Those species characteristic of inshore reefs were Cladophora fasicularis (Table 4; Fig. 5), Acetabularia calyculus (Table 4; Fig. 5), Jania adhaerens (Table 4) and Taenioma nanum (Table 4), Sphacelaria novae-hollandiae was abundant on both inshore and midshelf reefs (Table 4; Fig. 5). Taxa characteristic of mid- and outershelf reefs were

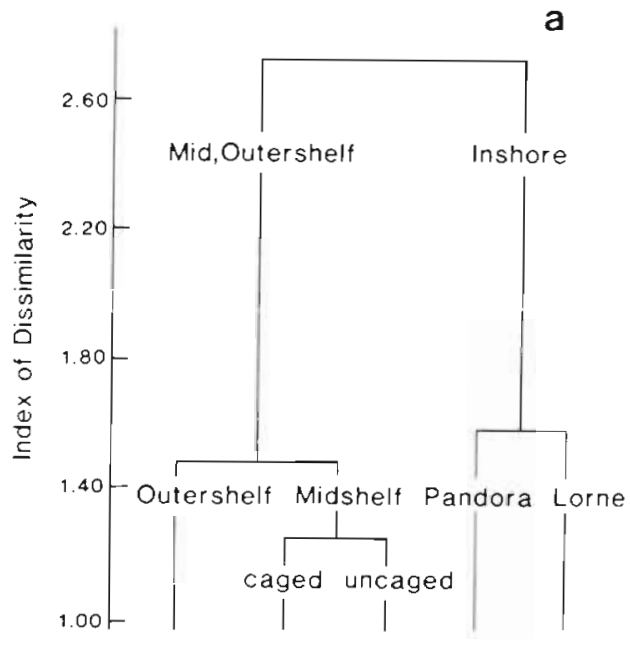

b

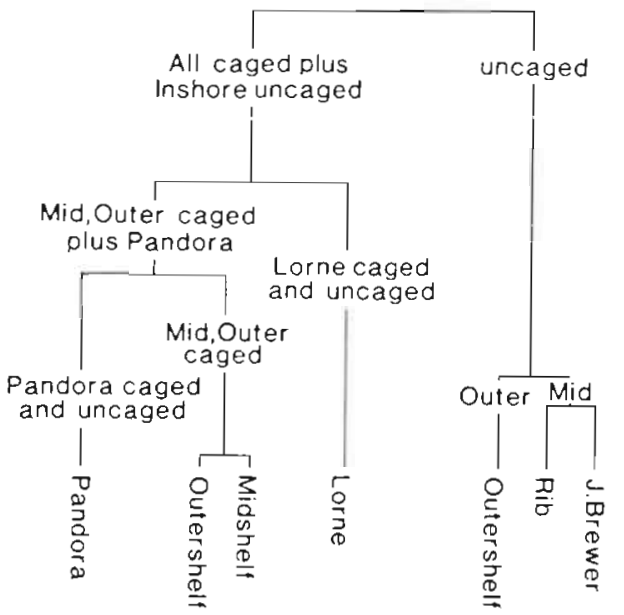

Fig. 4. Dendrogram from the classification analysis of the 30 most common taxa of algae from Table 1 (a) and from a classification analysis of the same taxa excluding the crustose coralline alga Porolithon onkodes (b). Each split in the dendrograms results in 2 significantly different groups (test of Sandland \& Young 1979a, b; 
Table 3. List of the 10 taxa of turf algae accounting for most of the variability attributable to cross-shelf location in Fig. $4 \mathrm{~b}$. The Cramer Value varies from 0 to 1 and indicates the relative contribution of a taxon to the discrimination between the 2 groups characterized by inshore reefs (Pandora, Lorne) and mid-plus outershelf reefs. Location where each taxon is most abundant is indicated by: $I$, inshore; $M$, midshelf; $O$, outershelf

\begin{tabular}{|lcc|}
\hline Algal taxon & $\begin{array}{c}\text { Cramer } \\
\text { Value }\end{array}$ & $\begin{array}{c}\text { Location } \\
\text { where taxon } \\
\text { most abundant }\end{array}$ \\
\cline { 1 - 2 } Cladophora fasicularis & 0.717 & $\mathrm{I}$ \\
?Pseudopringsheimia & 0.707 & $\mathrm{M}, \mathrm{O}$ \\
Sphacelaria novae-hollandiae & 0.573 & $\mathrm{I}, \mathrm{M}$ \\
Acetabularia calyculus & 0.555 & $\mathrm{I}$ \\
Nostocaceae & 0.528 & $\mathrm{M}, \mathrm{O}$ \\
Ceramium punctiforme & 0.524 & $\mathrm{M}, \mathrm{O}$ \\
Enteromorpha clathrata & 0.422 & $\mathrm{M}, \mathrm{O}$ \\
Polysiphonia scopulorum & 0.392 & $\mathrm{O}$ \\
Jania adhaerens & 0.351 & $\mathrm{I}$ \\
Taenioma nanum & 0.318 & $\mathrm{I}$ \\
\hline
\end{tabular}

?Pseudopringsheimia (Table 4), the Nostocacean assemblage (Table 4; Fig. 6), Ceramium punctiforme (Table 4; Fig. 6) and Enteromorpha clathrata (Table 4;
Fig. 7). Polysiphonia scopulorum and Lobophora variegata were most abundant on outershelf reefs (Table 4 ; Fig. 7).

Few taxa were abundant across most of the continental shelf. The Oscillatoriacean assemblage (Table 4 ; Fig. 6) and?Pseudopringsheimia (Table 4) were exceptions to this. High within-location variability in abundance resulted in lack of clear cross-shelf patterns for many species.

The taxa contributing most to the discrimination between the EAC on caged blocks with that on uncaged blocks for mid- and outershelf reefs in Fig. $4 \mathrm{~b}$ are listed in Table 5 and an estimate of the percentage cover of these taxa on caged and uncaged substrata at each of the 6 reefs is provided in Table 4. Four species were a dominant component of the EAC on caged but not uncaged blocks on the mid-and outershelf reefs. These were Enteromorpha clathrata (Table 4; Fig. 7), Polysiphonia infestans (Table 4; Fig. 7), Polysiphonia sphaerocarpa (Table 4; Fig. 8) and Ceramium flaccidum (Table 4; Fig. 8). Four other taxa were far more abundant on caged than uncaged blocks on midand outershelf reefs. These were Herposiphonia secunda f. tenella (Table 4). Centroceras clavulatum, the Oscillatoriacean assemblage (Table 4; Fig. 6) and

Table 4. Estimated mean \% canopy cover of the most common algal turf species (defined as having a mean $\%$ cover 1 ) $2 \%$ at the reef and in the treatment concerned). C: caged treatment, U: uncaged treatment. Note that total \% covers for caged treatments at Myrmidon and Dip reefs exceed $100 \%$. This is because canopy cover rather than actual surface cover is estimated and also in some cases Category 4 abundances are arbitanly given a cover estimate above the real value

\begin{tabular}{|c|c|c|c|c|c|c|c|c|c|c|c|c|}
\hline \multirow[t]{3}{*}{ Algal taxon } & \multicolumn{4}{|c|}{ Inshore } & \multicolumn{4}{|c|}{ Midshelf } & \multicolumn{4}{|c|}{ Outershelf } \\
\hline & \multicolumn{2}{|c|}{ Pandora } & \multicolumn{2}{|c|}{ Lorne } & \multicolumn{2}{|c|}{ Rib } & \multicolumn{2}{|c|}{ John Brewer } & \multicolumn{2}{|c|}{ Myrmidon } & \multicolumn{2}{|c|}{ Dip } \\
\hline & C & $\mathrm{U}$ & $\mathrm{C}$ & $\mathrm{U}$ & $\mathrm{C}$ & U & C & $\mathrm{U}$ & $\mathrm{C}$ & $\mathrm{U}$ & $\mathrm{C}$ & U \\
\hline Ceramium ?codii & & & & & & & & & & & 2.03 & \\
\hline C. flaccidum & 6.90 & & & & 9.77 & & & & & & 24.8 & \\
\hline C. punctiforme & & & & & & 2.67 & 2.36 & 3.00 & 4.23 & 3.87 & 9.50 & 7.10 \\
\hline Chondria sp. 3 & & & & 4.27 & & & & & & & & \\
\hline Herposiphonia secunda & & & & & & & & & & & & \\
\hline f. tenella & & & & & 3.8 & & 2.53 & & & & 15.7 & \\
\hline Jania adhaerens & & & & 2.70 & & & & & & & & \\
\hline Polysiphonia infestans & 5.83 & 4.13 & & & 4.57 & & & & 3.47 & & 8.37 & \\
\hline P. sphaerocarpa & 2.53 & 7.20 & & & 10.30 & & 4.60 & & 11.77 & & & \\
\hline P. scopulorum & & & & & & & & & 8.67 & 9.27 & 9.43 & \\
\hline Polysiphonia sp. 1 & & & & & & & 2.77 & 2.43 & & & 4.67 & 15.17 \\
\hline Taenioma nanum & 6.53 & & & & & & & & & & & \\
\hline Acetabularia calyculus & 9.52 & 2.33 & & & & & & & & & & \\
\hline Cladophora fasicularis & 4.53 & 3.27 & 3.16 & 3.10 & & & & & & & & \\
\hline Enteromorpha clathrata & & & & & 13.90 & & 6.60 & & 31.67 & & 11.15 & \\
\hline ?Pseudopringsheimia & & 4.45 & & & 4.3 & 5.0 & 3.33 & 6.73 & 4.37 & 4.83 & 14.2 & 10.47 \\
\hline Giffordia mitchellae & 4.3 & 21.0 & & & 6.73 & & 17.3 & 2.53 & & & & \\
\hline Lobophora variegata & & & & & & & & & 9.33 & & 9.60 & \\
\hline Padina sp. & 2.77 & & & & & & & & & & & \\
\hline Sphacelaria novae- & & & & & & & & & & & & \\
\hline hollandiae & 7.00 & 4.67 & 60.13 & 36.03 & 9.13 & & 24.70 & & & & 4.00 & \\
\hline Lyngbya majuscula & 3.07 & 3.40 & & & & & & & & & & \\
\hline Nostocaceae & & & & & & & 3.70 & 12.3 & 16.23 & 10.83 & 19.50 & 13.20 \\
\hline Oscillatoriaceae & 10.90 & 10.60 & 4.83 & 7.07 & 4.67 & & 4.57 & 3.30 & 13.93 & 2.10 & 9.60 & 3.70 \\
\hline
\end{tabular}



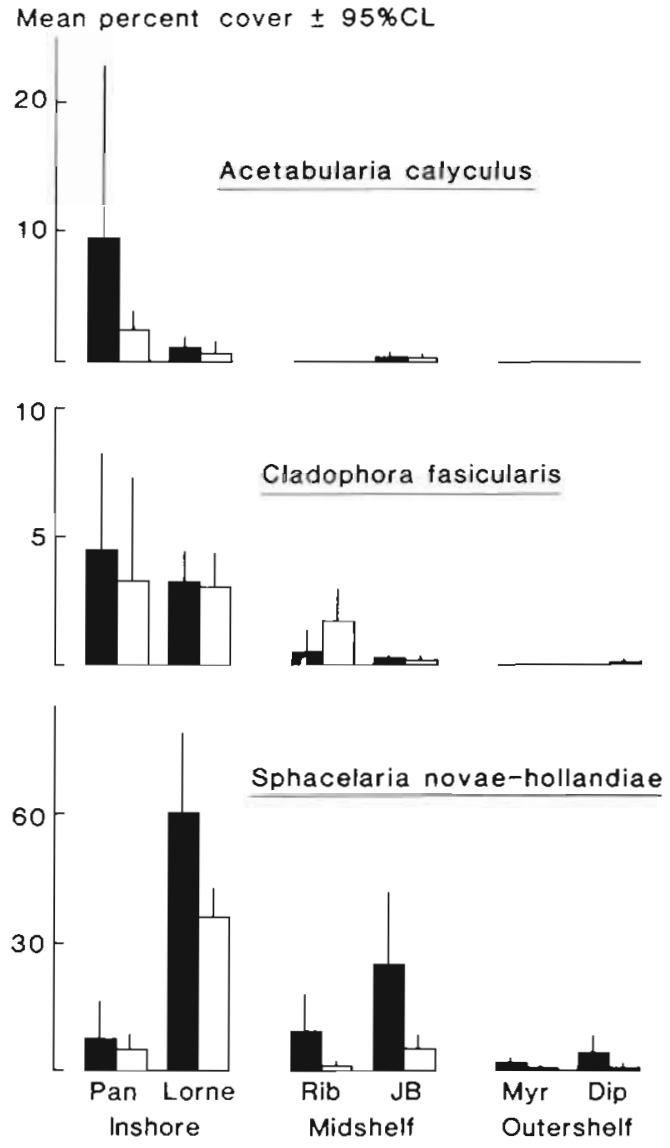

Fig. 5. Mean \% cover of 3 species of algae on caged (black bars) and uncaged (white bars) blocks on reefs across the continental shelf. Sites are pooled for each reef. Reefs as in Fig. 3

Sphacelaria novae-hollandiae (Table 4; Fig. 5). Lobophora variegata was more abundant on caged than uncaged blocks on outershelf reefs (Table 4 ; Fig. 7) and Giffordia mitchellae was more abundant on caged than uncaged blocks on midshelf reefs (Table 4; Fig. 8). ?Pseudopringsheimia and Jania adhaerens tended to have greater abundance on uncaged than caged blocks (Table 4).

Several taxa were abundant on uncaged blocks on inshore reefs, but occurred in high abundance on midand outershelf reefs on caged blocks only. These included Sphacelaria novae-hollandiae (Fig. 5), the Oscillatoriacean assemblage (Fig. 6), Polysiphonia infestans (Fig. 7), Ceramium flaccidum, Polysiphonia sphaerocarpa and Giffordia mitchellae (all Fig. 8).

\section{DISCUSSION}

This study provides the first quantitative description of the composition and abundance of species compris-
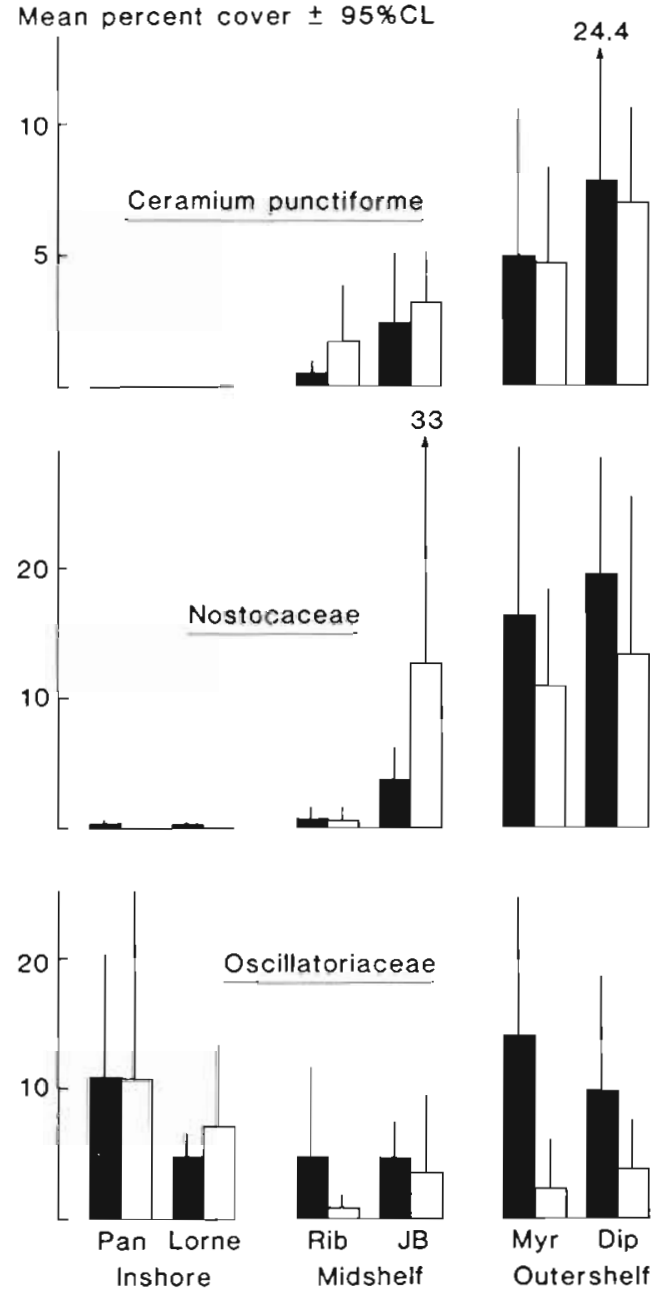

Fig. 6. Caption as for Fig. 5

ing the epilithic algal community (EAC) on coral reefs of the central Great Barrier Reef (GBR). In addition, it describes how this community varies in the presence and short-term absence of large grazing organisms, and how it varies between reefs at different locations on the continental shelf

The EAC was characterized by a high species richness and a large proportion of 'rare' species $(63 \%)$. Only 30 species were classed as common, abundant or dominant in terms of occurrence; 15 of these accounted for most of the canopy (Tables 1 \& 4). Comparable information is rare in the published literature, because of the great taxonomic difficulties associated with the EAC on coral reefs throughout the world. These taxonomic difficulties are beginning to be overcome (Kraft \& Huisman 1981, Cribb 1983, Huisman \& Kraft 1984, Huisman 1985, Price \& Scott unpubl,). Previous publications on species composition of algal turfs on the GBR consist mainly of lists with presence/absence information for various sites (e.g. Price et al. 1976, Borowitzka 


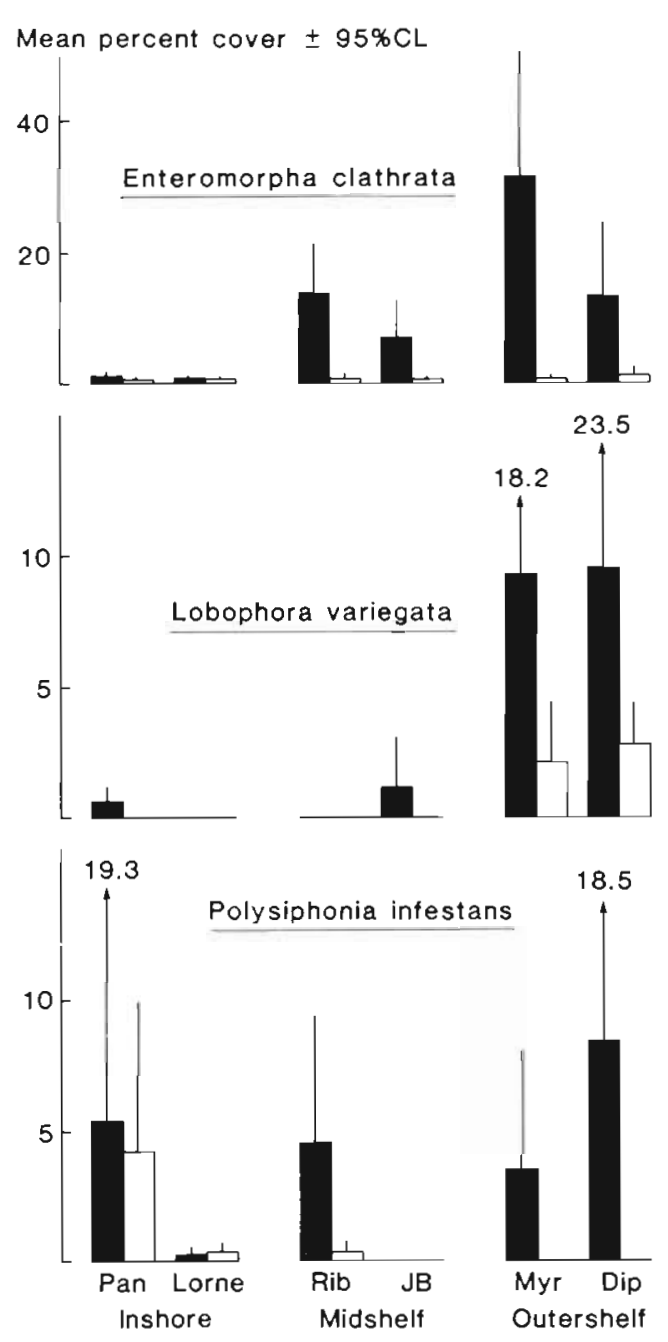

Fig. 7. Caption as for Fig. 5

Table 5. List of the 10 taxa of turf algae accounting for most of the variability attributable to the caging treatment on midand outershelf reefs in Fig. 4b. Cramer Value varies from 0 to 1 and indicates the relative contribution of a taxon to the discrimination between the 2 groups characterized by caged and uncaged substrata. All taxa except ?Pseudopringsheimia and Jania adhaerens were more abundant on caged than uncaged substrata

\begin{tabular}{|lc|}
\hline Algal taxon & Cramer Value \\
\hline Enteromorpha clathrata & 0.822 \\
Polysiphonia infestans & 0.539 \\
Polysiphonia sphaerocarpa & 0.502 \\
Ceramium flaccidum & 0.490 \\
Herposiphonia secunda f. tenella & 0.413 \\
Centroceras clavulatum & 0.375 \\
Oscillatoriaceae & 0.374 \\
?Pseudopringsheimia & 0.371 \\
Jania adhaerens & 0.329 \\
Sphacelaria novae-hollandiae & 0.305 \\
\hline
\end{tabular}
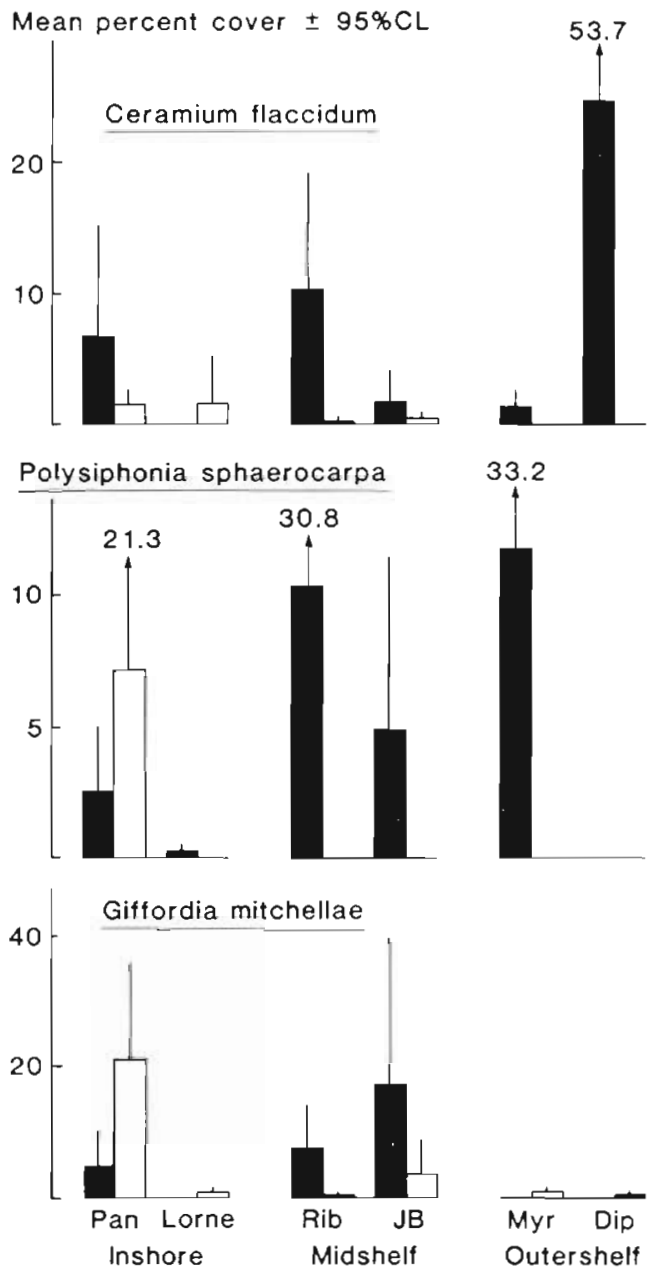

Fig. 8. Caption as for Fig. 5

et al. 1978, Saenger 1979, Ngan \& Price 1979, Hatcher \& Larkum 1983, Lewis 1984, Garnett et al. 1985). Sammarco (1983) provided some quantitative information on the abundance of individual species in the EAC within the territories of an herbivorous pomacentrid.

Although a variety of species have been recorded for other tropical reefs, a considerable number of algal genera observed on the GBR are common components of the EAC elsewhere (e.g. Caribbean: Wanders 1977 , van den Hoek et al. 1978, Carpenter 1981, 1985b; Hawaii: Hixon \& Brostoff 1981, McDermid 1985; Guam: Tsuda \& Kami 1973). These include Centroceras, Ceramium, Gelidiella, Herposiphonia, Hypnea, Jania, Laurencia, Polysiphonia, Taenioma (Rhodophyta), Cladophora, Enteromorpha (Chlorophyta), Dictyota, Giffordia, Sphacelaria (Phaeophyta), Calothrix and Lyngbya (Cyanophyta).

This study demonstrated that short-term exclusion of large herbivorous grazing organisms had a significant effect upon the abundance of individual species and hence the composition of the EAC. Because the study 
formed part of a much larger one investigating the rate of production of algal tissue and the rate of trophic exchange between the EAC and large grazers (Williams et al. 1986, Russ unpubl, data), a feature of interest was the identification of the species most likely to account for the very high rates of primary productivity recorded on these reefs (e.g. Barnes 1983) and the high rates of trophic exchange between the EAC and grazers (Williams et al. 1986, Russ unpubl. data). Those taxa most likely to account for a large proportion of the algal production, and of the food of large, herbivorous grazers on the reefs studied, are the 8 listed in Table 5 which were more abundant on caged than uncaged blocks, plus Giffordia mitchellae and Lobophora variegata.

The effect of excluding grazers on the composition and abundance of individual species in the EAC was far greater on mid-and outershelf reefs than on reefs inshore. The canopy cover of the algal turfs on caged and uncaged blocks on the inshore reefs did not differ significantly (Fig. 3). Caged blocks on mid- and outershelf reefs had significantly higher percentage cover of algal turfs and significantly lower cover of the crustose coralline Porolithon onkodes (Fig. 3). Furthermore, caged and uncaged blocks from inshore reefs showed strong affinities in terms of composition of species to caged blocks from mid-and outershelf reefs (Fig. 4b). These findings are in agreement with published information that herbivorous, grazing fishes occur in significantly lower abundance on inshore reefs than on midand outershelf reefs (Williams 1982, Williams \& Hatcher 1983, Russ $1984 \mathrm{a}$, b). The differential effect of grazers was confirmed by the fact that in terms of turnover of algal biomass $\left(\mathrm{gC} \mathrm{m} \mathrm{m}^{-2} \mathrm{~d}^{-1}\right)$ the rate of production of algal tissue and trophic exchange to large grazers was significantly less on inshore reefs than on mid- and outershelf reefs (Williams et al. 1986, Russ unpubl. data). This strong interaction between the impact of grazers and cross-shelf location makes it difficult to identify any cross-shelf trends in the abundance of algal species which are independent of the effect of grazing. Nevertheless, although a good degree of cross-shelif difference in the composition of the EAC occurred, particularly from inshore to mid-shelf (Fig. $4 \mathrm{a}_{i}$ Tables 3 \& 4 ), the pattern is not as clearly defined as that for other groups of organisms studied to date (fish: Williams 1982, Williams \& Hatcher 1983, Russ 1984a, b; hard corals: Done 1982; calcified green algae: Drew 1983; soft corals: Dinesen 1983). Part of the reason for this may be that a large number of common species which occur at several locations have very large variability in abundance within-locations.

A great deal of information exists on the effect of herbivorous grazers on the distribution and abundance of macroalgal species on coral reefs (e.g. Ogden et al.
1973, Ogden \& Lobel 1978, Carpenter 1981, 1986, Hay 1981, Hatcher 1983, Hay \& Goertemiller 1983, Hay et al. 1983, Hixon 1983, Lewis 1985, 1986) and some of this work has been extended to spatial scales of tens of kilometres (Hay 1984). There is information also on the effect of grazing on the composition and species richness of algal turfs (e.g. Day 1977, Borowitzka et al. 1978, Borowitzka 1981, Carpenter 1981, 1986, Sammarco 1983, Hatcher 1983, Hixon 1983) but much of this work has been carried out at small spatial scales, and often at single sites. The effect of excluding grazers on the species richness of communities of algal turfs appears to depend on the duration of exclusion. Shortterm exclusion (weeks to a few months) leads often to an increase in species richness whilst longer-term exclusion ( 3 to $12 \mathrm{mo}$ ) may lead to a reduction in species richness but these patterns are by no means universal (e.g. Jernakoff 1985; see also reviews by Hixon 1983, Underwood 1983). In the present study, short-term exclusion of grazers had no significant effect on species richness at the inshore reefs, but did increase species richness significantly at 3 of the 4 midand outershelf reefs (Fig. 3). This appears to be the first demonstration of the effect of short-term exclusion of grazers on species richness of algae over a large scale gradient of grazing pressure.

In studies of the effects of grazing on rates of nitrogen fixation by blue-green algae in the central GBR, Sammarco (1983) and Wilkinson et al. (1984, 1985) reported that blue-green algae were more abundant on grazed than lightly grazed or ungrazed substrata and suggested that they were less abundant on inshore reefs than mid-and outershelf reefs. Eight taxa of bluegreen algae were recorded in the present study. Two taxonomic groupings were classed as dominant and a third taxon classed as a common component of the EAC (Table 1). The effects of grazing pressure and crossshelf location on the abundance of blue-green algae in the present study differ from those reported by Sammarco and Wilkinson et al. The Nostocacean and Oscillatoriacean assemblages were more abundant on ungrazed than grazed surfaces on mid-and outershelf reefs (Fig. b; Table 4), although the Nostocacean assemblage at John Brewer reef was an exception. The Oscillatoriacean assemblage and monospecific mats of Lyngbya majuscula were equally abundant on grazed and ungrazed surfaces on inshore reefs (Fig. 6; Table 4). Only the Nostocacean assemblage had a significantly smaller abundance on inshore reefs than midand outershelf reefs (Fig. 6). The Oscillatoriacean assemblage (including separate records of Lyngbya majuscula) was more abundant on inshore than midshelf reefs (Fig. 6; Table 4). Wilkinson et al. (1984) discussed other studies which contrasted with their contention that the abundance of blue-green algae and 
the rate of nitrogen fixation are greater on heavily grazed than lightly grazed surfaces.

In summary, the species of the EAC which are likely to account for a large proportion of the algal production and the food of large herbivorous grazers on reefs along a cross-shelf transect in the central GBR have been identified. Grazers had a greater impact on the composition and abundance of the EAC on mid-and outershelf reefs than inshore reefs. This is consistent with previous findings that large, herbivorous grazing fishes occur in significantly lower abundance on inshore reefs than mid-and outershelf reefs (Williams 1982, Williams \& Hatcher 1983, Russ 1984a, b).

Acknowledgements. This project would not have been possible without access to the extensive facilities of the Australian Institute of Marine Science, in particular the research vessels. The second author was supported by a Queen's Fellowship in Marine Science. Alan Dartnall, Ed Drew, Ian Price, Tony Underwood and David Williams read the manuscript. Russell Garrick identified blue-green algae, and John Chisholm identified crustose coralline algae. We thank Peter Eden, skipper of the R.V. Sirius, and Marietta Thyssen and Fiona Jones who prepared the figures. This is Contribution No. 356 of the Australian Institute of Marine Science.

\section{LITERATURE CITED}

Barnes, D. J. (1983). Profiling coral reef productivity and calcification using $\mathrm{pH}$ and oxygen electrodes. J. exp. mar. Biol. Ecol. 66: 149-161

Borowitzka, M. A. (1981). Algae and grazing in coral reef ecosystems. Endeavour 5: 99-106

Borowitzka, M. A., Larkum, A. W. D., Borowitzka, L. J. (1978). A preliminary study of algal turf communities of a shallow coral reef lagoon using an artificial substratum. Aquat. Bot. 5: $365-381$

Bray, J. R., Curtis, J. T (1957). An ordination of the upland forest communities of southern Wisconsin. Ecol. Monogr $27 \cdot 325-349$

Burr, E. J. (1970). Cluster sorting with mixed character types. II. Fusion strategies. Aust. Comput. J. 1: 98-103

Carpenter, R. C. (1981). Grazing by Diadema antillarum Philippi and its effects on the benthic algal community. $J$. mar. Res. 39: 749-765

Carpenter, R. C. (1985a). Relationships between primary production and irradiance in coral reef algal communities. Limnol. Oceangr. 30: 784-793

Carpenter, R. C. (1985b). Sea urchin mass-mortality: effects on reef algal abundance, species composition and metabolism and other coral reef herbivores. Proc. 5th Int. Coral Reef Congr., Tahiti 4: 53-60

Carpenter, R. C. (1986). Partitioning herbivory and its effects on coral reef algal communities. Ecol. Monogr. 56: $345-363$

Cribb, A. B. (1983). Marine algae of the southern Great Barrier Reef - Rhodophyta. Aust. Coral Reef Soc. Handbook No. 2

Day, R. W. (1977). Two contrasting effects of predation on species richness in coral reef habitats. Mar. Biol. 44: 1-5

Dinesen, Z. D. (1983). Patterns in the distribution of soft corals across the central Great Barrier Reef. Coral Reefs 1: $229-236$
Done, T J. (1982). Patterns in the distribution of coral communities across the central Great Barrier Reef. Coral Reefs 1: $95-107$

Drew, E. A. (1983). Halimeda biomass, growth rates and sediment generation on reefs in the central Great Barrier Reef Province. Coral Reefs 2: 101-110

Garnett, S. T., Price, I. R., Scott, F. J. (1985). The diet of the green turtle, Chelonia mydas (L.), in Torres Strait. Aust. Wildl. Res. 12: 103-112

Gladfelter, E. H., Kinsey, D. W. (1985). Metabolism, calcification and carbon production. Proc. 5th Int. Coral Reef Congr., Tahiti 4: 505-542

Hatcher, B. G. (1981). The interaction between grazing organisms and the epilithic algal community of a coral reef: a quantitative assessment. Proc. 4 th Int. Coral Reef Symp., Manila 2: 515-524

Hatcher, B. G. (1983). Grazing in coral reef ecosystems. In: Barnes, D. J. (ed.) Perspectives on coral reefs. Australian Institute of Marine Science, Townsville, p. 164-179

Hatcher, B. G., Larkum, A. W. D. (1983). An experimental analysis of factors controlling the standing crop of the epilithic algal community on a coral reef. J. exp. mar. Biol. Ecol. 69: 61-84

Hay, M. E. (1981). Spatial patterns of grazing intensity on a Caribbean barrier reef: herbivory and algal distribution. Aquat. Bot. 11.97-109

Hay, M. E. (1984). Patterns of fish and urchin grazing on Caribbean coral reefs: are previous results typical? Ecology 65 (2): 446-454

Hay, M. E., Colburn, T., Downing, D. (1983). Spatial and temporal patterns in herbivory on a Caribbean fringing reef: the effects of plant distribution. Oecologia (Berl.) 58 299-308

Hay, M. E., Goertemiller, T. (1983). Between-habitat differences in herbivore impact on Caribbean coral reefs. In: Reake, M. L. (ed.) The ecology of deep and shallow coral reefs. Symposia Series for Undersea Research, Vol. 1, p. 97-102

Hixon, M. A. (1983). Fish grazing and community structure of reef corals and algae: a synthesis of recent studies. In: Reake, M. L. (ed.) The ecology of deep and shallow reefs. Symposia Series for Undersea Research, Vol. 1 Office of Undersea Research, NOAA, Rockville, Maryland, p. 79-87

Hixon, M. A., Brostoff, W. N. (1981). Fish grazing and community structure of Hawaiian reef algae. Proc. 4th Int. Coral Reef Symp., Manila 2: 507-514

Hoek, C. van den, Breeman, M. A., Bak, R. P. M., Buurt, G. van (1978). The distribution of algae, corals and gorgonians in relation to depth, light attenuation, water movement and grazing pressure in the fringing coral reef of Curacao, Netherlands Antilles. Aquat. Bot. 5: 1-46

Huisman, J. M. (1985). Rhipidothamnion secundum gen. et. sp. nov. and Spermothamnion miniatum sp. nov. (Ceramiaceae, Rhodophyta) from eastern Australia. Phycologia 24 (1): 55-66

Huisman, J. M., Kraft, G. T. (1984). The genus Balliella Itono and Tanaka (Rhodophyta: Ceramiaceae) from eastern Australia. J. Phycol. 20 (1): 73-82

Jernakoff, P. (1985). An experimental evaluation of the influence of barnacles, crevices and seasonal patterns of grazing on algal diversity and cover in an intertidal barnacle zone. J. exp. mar. Biol. Ecol. 88: 287-302

Kennelly, S. J. (1983). An experimental approach to the study of factors affecting algal colonization in a sublittoral kelp forest. J. exp. mar. Biol. Ecol. 68: 257-276

Kraft, G. T., Huisman, J. M. (1981). New record of the marine red alga Cubiuculoporum (Gigartinales) from the southern Great Barrier Reef. J. Phycol. 17: 278-280 
Lance, G. N., Williams, W. T (1977). Attribute contributions to a classification. Aust. Comput. J. 9: 128-129

Lewis, J. A. (1984). Checklist and bibliography of benthic marine macroalgae recorded from northern Australia. I. Rhodophyta. Report MRL-R-912, Materials Research Laboratories, Melbourne

Lewis, S. M. (1985). Herbivory on coral reefs: algal susceptibility to herbivorous fishes. Oecologia (Berl.) 65: 370-375

Lewis, S. M. (1986). The role of herbivorous fishes in the organization of a Caribbean reef community. Ecol. Monogr. 56: 183-200

McDermid, K. G. (1985). Mosaic pattern and patch dynamics of an intertidal algal community in Hawaii. Proc. 5th Int. Coral Reef Congr., Tahiti 4: 67-72

Ngan, Y., Price, I. R. (1980). Distribution of intertidal benthic algae in the vicinity of Townsville, tropical Australia. Aust. J. mar. Freshwat. Res. 31: 175-191

Ogden, J. C., Brown, R., Salesky, N. (1973). Grazing by the echinoid Diadema antillarum Philippi: formation of halos around West Indian patch reefs. Science 182: 715-717

Ogden, J. C., Lobel, P. S. (1978). The role of herbivorous fishes and urchins in coral reef communities. Environ. Biol. Fish. 3: $49-63$

Price, I. R., Larkum, A. W. D., Bailey, A. (1976). Check list of marine benthic plants collected in the Lizard Island area. Aust. J. Plant Physiol. 3: 1-8

Russ, G. (1984a). Distribution and abundance of herivorous grazing fishes in the central Great Barrier Reef. I. Levels of variability across the entire continental shelf. Mar. Ecol. Prog. Ser. 20: 23-34

Russ, G. (1984b). Distribution and abundance of herbivorous grazing fishes in the central Great Barrier Reef. II. Patterns of zonation of mid-shelf and outershelf reefs. Mar. Ecol. Prog. Ser. 20: 35-44

Russ, G. R. (in press). Is rate of removal of algae by grazers reduced inside territories of tropical damselfishes? J. exp. mar. Biol. Ecol.

Saenger, P. (1979). Records of subtidal algae from the Swains Reef Complex, Great Barrier Reef, Queensland. Proc. R. Soc. Queensl. 90: 51-55

Sammarco, P. W. (1983). Effects of fish grazing and damselfish territoriality on coral reef algal. I. Algal community structure. Mar. Ecol. Prog. Ser. 13: 1-14

Sandland, R. L., Young, P. C. (1979a). Probabilistic tests and stopping rules associated with hierarchical classification techniques. Aust. J. Ecol. 4: 399-406
Sandland, R. L., Young, P. C. (1979b). Tables of probabilities associated with the fission of replicate samples in classification. CSIRO Aust. Div. Fish. Oceanogr. Rep. 108

Tsuda, R. T., Kami, H. T (1973). Algal succession on artificial reefs in a marine lagoon environment in Guam. J. Phycol. 9: $260-264$

Underwood, A. J. (1981). Techniques of analysis of variance in experimental marine biology and ecology. Oceanogr. mar. Biol. A. Rev. 19: 513-605

Underwood, A. J. (1983). Spatial and temporal problems in the design of experiments with marine grazers. Proc. 1st Great Barrier Reef Conference, James Cook University, Townsville, p. $251-256$

Wanders, J. B. W. (1977). The role of benthic algae in the shallow reef of Curaçao (Netherlands Antilles). III. The significance of grazing. Aquat. Bot. 3: 357-390

Wilkinson, C. R., Sammarco, P. W., Trott, L. A. (1985). Seasonal and fish grazing effects on rates of nitrogen fixation on coral reefs (Great Barrier Reef, Australia). Proc. 5th Int. Coral Reef Congr., Tahiti 4: 61-65

Wilkinson, C. R., Williams, D. McB., Sammarco, P. W., Hogg R. W., Trott, L. A. (1984). Rates of nitrogen fixation on coral reefs across the continental shelf of the central Great Barrier Reef. Mar. Biol. 80: 255-262

Williams, D. McB. (1982). Patterns in the distribution of fish communities across the central Great Barrier Reef. Coral Reefs 1: 35-43

Williams, D. McB. (1983). Longitudinal and latitudinal variation in the structure of reef fish communities. Proc. 1st Great Barrier Reef Conference, James Cook University, Townsville, p. 265-270

Williams, D. McB., Hatcher, A. J. (1983). Structure of fish communities on outer slopes of inshore, midshelf and outershelf reefs of the Great Barrier Reef. Mar. Ecol. Prog. Ser. 10: 239-250

Williams, D. McB., Russ, G., Doherty, P. J. (1986). Reef fish: large-scale distribution and recruitment. Oceanus 29: $76-82$

Williams, W. T. (1971). Principles of clustering. Ann. Rev. Ecol. Syst. 2: 303-326

Williams, W T., Lance, G. N. (1977). Hierarchical classificatory methods. In: Enslien, K., Ralston, A., Wilf, W. S. (ed.) Statistical methods for digital computers, Vol. III. Wiley Interscience, New York, p. 269-295

Winer, B. J. (1971). Statistical principles in experimental design, 2nd edn. McGraw-Hill Koga-kusha, Tokyo

This article was presented by Dr J. S. Bunt; it was accepted for printing on April 8, 1987 